\title{
Monitoring Kualitas Air Berbasis Smart System Untuk Ketersediaan Air Bersih Desa Ciaruteun Ilir, Kec. Cibungbulang, Kab. Bogor
}

\author{
Hendra Jatnika ${ }^{\text {; M. Farid Rifai }}{ }^{2}$; Yudhi S. Purwanto ${ }^{3}$; Sely Karmila ${ }^{4}$ \\ 1, 2,3,4 Institut Teknologi PLN \\ ${ }^{1}$ h.jatnika@itpln.ac.id \\ ${ }^{2}$ m.farid@itpln.ac.id \\ ${ }^{3}$ y.purwanto@itpln.ac.id \\ ${ }^{4}$ sely_karmila@itpln.ac.id
}

\begin{abstract}
Ciaruteun Ilir Village, Cibungbulang sub-district, Bogor Regency is located on west of Bogor Regency, approximately $6 \mathrm{~km}$ to the sub-district capital. The village is experiencing difficulties in obtaining clean water that is suitable for consumption even though the village area has a river but is full of garbage. Even though the river is dirty, there are some people who are still using it, for example: for bathe. There are also people who make wells, but the water quality is not guaranteed to be suitable for consumption. As a result many people are affected by stomach and skin diseases. Monitoring system that can observe the water quality have become an urgent need for the villagers. This system is designed using a combination method of making prototype technology device and application. Testing method of the working model of these device and application was done through a process of repeated interaction between researchers and villagers. This technology and application that are designed using devices that are connected to an android application or computer so that users can use them both in real time and mobile modes to monitor and make decision about the usage of water for their health.
\end{abstract}

Keywords: Ciaruteun Ilir, clean water, monitoring system, water quality testing device

\begin{abstract}
ABSTRAK
Desa Ciaruteun Ilir, Kecamatan Cibungbulang, Kabupaten Bogor terletak di sebelah barat Kabupaten Bogor berjarak kurang lebih $6 \mathrm{~km}$ ke ibukota kecamatan. Desa ini mengalami kesulitan air bersih yang layak konsumsi padahal wilayah desa ini memiliki sungai yang cukup baik tetapi banyak dipenuhi oleh kotoran sampah. Sekalipun sungai tersebut kotor, masyarakat masih ada yang menggunakannya untuk mandi. Ada juga masyarakat yang membuat sumur, namun kualitas airnya belum terjamin untuk layak dikonsumsi, akibatnya banyak masyarakat yang terkena penyakit perut dan kulit. Sistem monitoring yang dapat memantau kualitas air saat ini telah menjadi kebutuhan yang mendesak bagi penduduk desa. Sistem yang dirancang mengunakan metode kombinasi pembuatan prototipe perangkat teknologi. Pengujian terhadap model kerja dari aplikasi dan perangkat ini melalui proses interaksi yang berulang-ulang antara peneliti dengan penduduk desa. Perangkat teknologi yang dirancang menggunakan perangkat/alat pendeksi yang dikoneksikan dengan aplikasi android atau perangkat komputer sehingga pengguna dapat menggunakannya baik secara realtime maupun mobile melakukan monitoring dan mengambil keputusan terhadap penggunaan air untuk kesehatannya.
\end{abstract}

Kata kunci: Ciaruteun Ilir, air bersih, sistem monitoring, perangkat pengujian kualitas air 


\section{KILAT}

Vol. 10, No. 1, April 2021, P-ISSN 2089-1245, E-ISSN 2655-4925

DOI: https://doi.org/10.33322/kilat.v10i1.1042

\section{PENDAHULUAN}

\subsection{Latar belakang}

Desa Cairuteun Ilir terletak disebelah utara Desa Cikodom Kecamatan Rupmin, sebelah selatan berbatasan langsung dengan Desa Leuweungkolot, sebelah barat berbatasan dengan Desa Cijujung, dan sebelah timur berbatasan dengan Desa Ciampea. Desa Ciaruteun Ilir khususnya Kampung Poncol merupakan merupakan daerah yang tertinggal.

Berdasarkan hasil survey lapangan dan wawancara yang telah dilakukan dengan Kepala Desa Ciaruteun Ilir bahwa hal utama penyebab desa ini tertinggal adalah pendidikan yang rata-rata masyarakatnya (85\%) hanya tamatan SMP dan SMA.

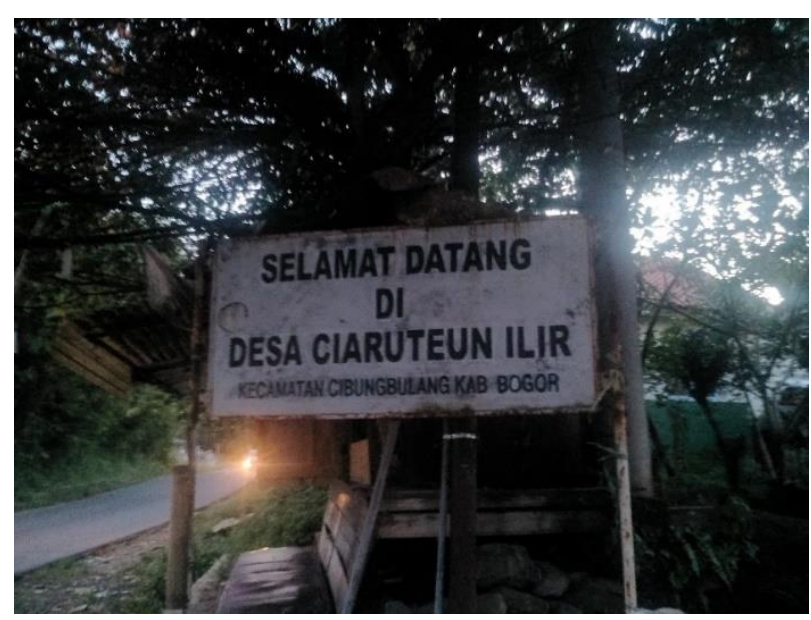

Gambar 1. Lokasi Desa Ciaruteun ilir

Namun jika dilihat dari sisi lain dan kebutuhan hidup sehari-hari masyarakat di desa Ciaruteun Ilir masih jauh dari sejahtera bahkan juga kesulitan untuk mendapatkan air bersih layak konsumsi, padahal secara geografis merupakan daerah yang dikelilingi oleh sungai. Wilayah desa ini juga masih terbatas suplai air bersih untuk konsumsi sementara potensi daerah secara geografi sangat potensial untuk mendapatkan air bersih karena desa ini dilalui oleh sungai yang cukup besar sekalipun sungainya masih kotor karena sampah, namun bukan sampah industri, melainkan sampah dedaunan dan sampah rumah tangga yang dibuang oleh masyarakat.

Selain sungai, desa ini juga memiliki 2 mata air gunung yang cukup bagus bahkan terkadang masyarakat meminum air tersebut secara langsung. Kendalanya adalah bahwa lokasinya terletak lebih kurang $1 \mathrm{Km}$ dari lokasi desa. Saat ini air yang dikonsumsi oleh masyarakat setiap hari adalah air sumur dengan kondisi air seadanya, air hujan di penampungan, sumber mata air, membeli air atau mengambil dengan cara berjalan kaki.

Dengan latar belakang di atas, kebutuhan terhadap sistem monitoring yang dapat memantau kualitas air saat ini dirasa sangat mendesak bagi penduduk desa supaya penguna dapat mengetahui kualitas dari air yang akan digunakan.

\subsection{Rumusan masalah}

Selain daripada hasil wawancara dengan perangkat desa dan masyarakat sekitar, kondisi terbaru Desa Ciaruteun Ilir didapat dari http://topbogor.com/warga-desa-ciaruteun-ilir-butuh-air- 
bersih [1]. Untuk mendapatkan air bersih, masyarakat harus mengantri di setiap sumber mata air, yang diantaranya berada di wilayah lingkungan RW. 09 yang dibangun oleh DPU Bekerjasama dengan PNPM KSM TARUNA NEGARA 09 BKM Mentari Tahun 2011.

Sumber mata air ini tidak pernah sepi dan menjadi tumpuan utama masyarakat desa untuk keperluan keluarga, baik untuk minum, memasak, maupun untuk mandi, cuci, kakus (MCK). Kondisi kualitas air yang ada tidak pernah dipermasalahkan oleh masyarakat sehingga tidak diketahui secara pasti kondisi/kualitas air tersebut untuk kesehatan.

Dari rumusan permasalahan tersebut maka pertanyaan penelitian yang muncul adalah:

a. Bagaimana letak geografis Desa Ciaruteun Ilir Kabupaten Bogor?

b. Bagaimana dan apa dampak permasalahan kualitas air yang terjadi di Desa Ciaruteun Ilir?

c. Bagaimana pembuatan sistem monitoring kualitas air berbasis Smart System untuk ketersediaan air bersih Desa Ciaruteun Ilir?

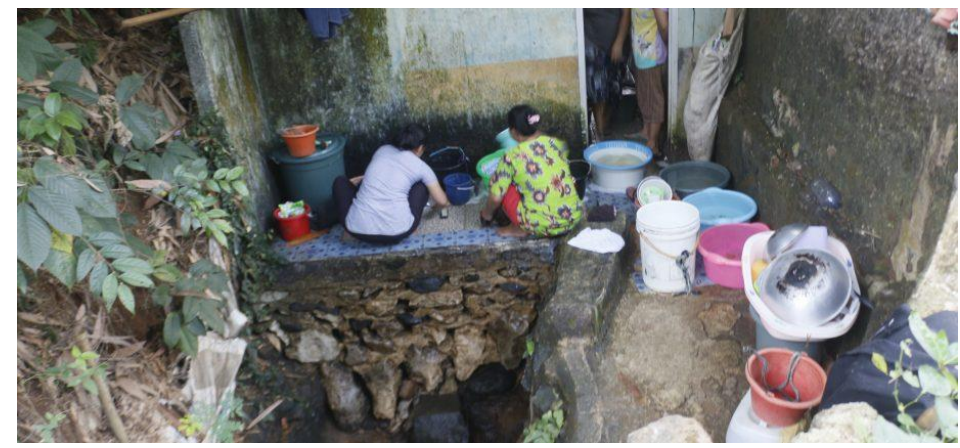

Gambar 2. Penggunaan air tanah penduduk Desa Ciaruteun Ilir
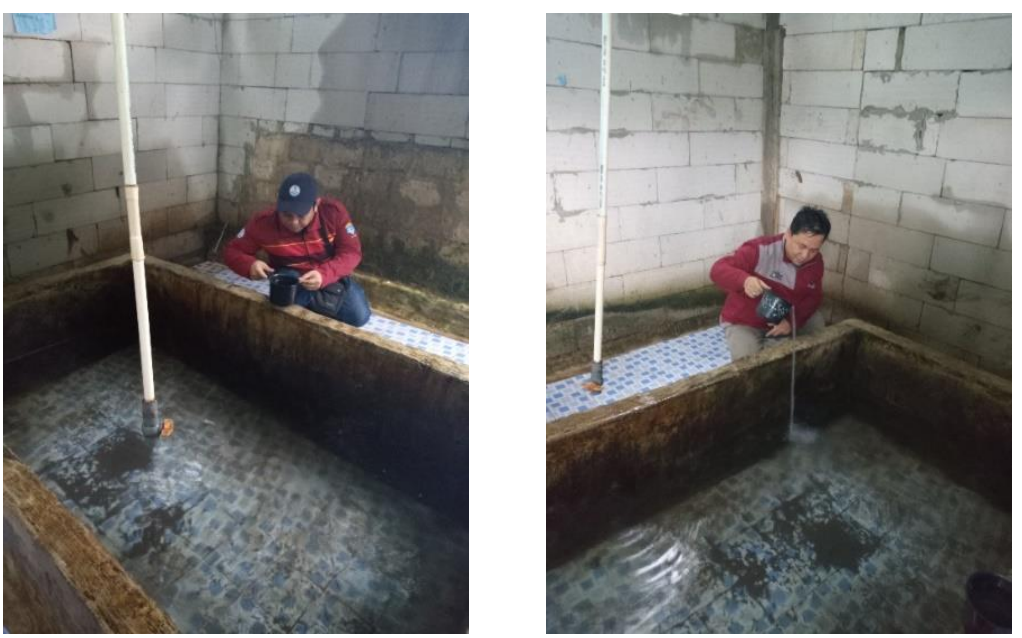

Gambar 3. Survey Awal Kualitas air Penampungan Desa Ciaruteun Ilir

Berdasarkan kondisi di atas, maka tim memutuskan untuk membuat sebuah alat yang terintegrasi pada sebuah aplikasi untuk dapat mengetahui dan memonitor kualitas air sebelum digunakan atau dikonsumsi oleh masyarakat. Alat tersebut dinamai ALUKAR (Alat Ukur Kualitas Air). 


\section{KILAT}

Vol. 10, No. 1, April 2021, P-ISSN 2089-1245, E-ISSN 2655-4925

DOI: https://doi.org/10.33322/kilat.v10i1.1042

\section{KAJIAN PUSTAKA}

Penelitian sebelumnya berfungsi untuk analisa dan memperkaya pembahasan penelitian, serta membedakannya dengan penelitian yang sedang dilakukan, berikut State of the Art Smart System untuk ketersediaan air bersih Desa Ciaruteun Ilir yang digunakan peneliti.

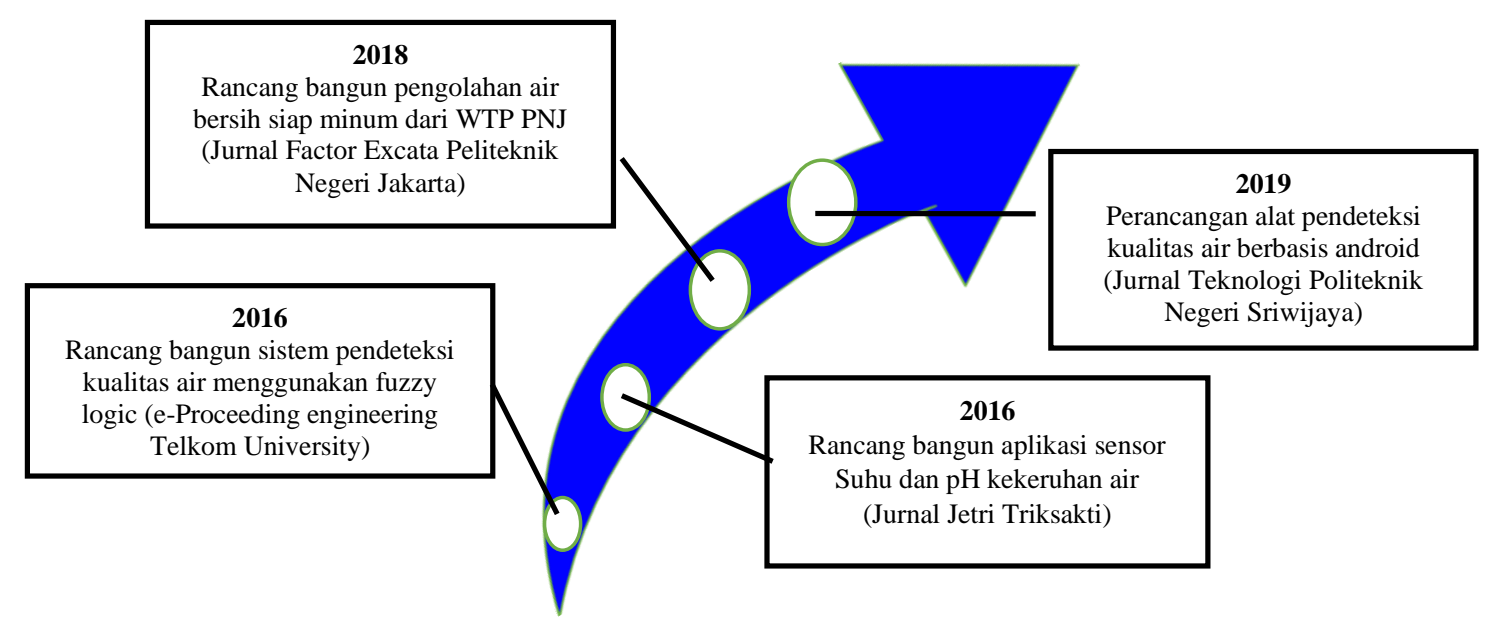

Gambar 4. Roadmap Penelitian

Berikut adalah Jurnal penelitian utama yang dijadikan sebagai referensi utama dalam melakukan penelitian, berikut adalah penjelasannya.

Penelitian (1) yang dilakukan Miftah, Erwin dan Prasetya [2] penelitian tentang rancang bangun sistem pendeteksi kualitas air menggunakan fuzzy logic. Sistem ini menggunakan sensor $\mathrm{pH}$ dan LDR dapat dibuatnya alat pengontrol kualitas air dengan memenuhi 2 dari 3 syarat kualitas air yang layak di konsumsi oleh masyarakat. Nilai yang dihasilkan sensor LDR tergantung dari seberapa terang penerangan ruangan yang digunakan pada saat pengujian alat. Keakurasian pada sensor $\mathrm{pH}$ mencapai lebih dari $80 \%$. Tawas dapat menjernihkan air dengan cara sedimentasi partikel-partikel yang terdapat pada air dengan waktu yang relatif lama. Penelitian (2) yang dilakukan Fitri, Irawan, dan Lindawati [3] merancang alat pendeteksi kualitas air berbasis android berfungsi sebagai media guna untuk mempermudah masyarakat melakukan percobaan antar air yang layak di konsumsi atau tidak layak untuk di konsumsi. Kelebihan pada alat ini, masyarakat akan terhindar dari segala penyakit. Setelah melakukan perancangan alat ini, langkah selanjutnya ialah melakukan pengujian kinerja alat pendeteksi kualitas air $(\mathrm{pH})$.

Pada penelitian (3) yang dilakukan Reza [4] menghasilkan pengolahan air bersih siap minum dari WTP PNJ layak untuk dikonsumsi dan juga sudah lolos uji dari berbagai lembaga. Namun dengan adanya sumber yang tidak terlalu baik dengan kadar $\mathrm{pH}$ yang terlalu rendah (rata-rata 4), serta suhu yang cukup tinggi(rata-rata $28^{\circ} \mathrm{C}$ ) maka sumber WTP ini perlu mendapat perawatan khusus. Perawatan ini dimaksudkan agar dapat mempermudah cara kerja mesin WTP sehingga lebih awet dan biaya operasionalnya lebih murah. Penelitian (4) yang dilakukan Ahmad, Sabriasyah dan Hurriayatul [5] membahas perlunya menjaga kualitas air tambak baik dengan cara memasukkan semua sensor, antara lain sensor $\mathrm{pH}$, sensor kekeruhan dan sensor suhu, setelah itu diproses melalui 
mikrokontroller Arduino Nano dan ditampilkan nilai semua sensor tersebut pada Lcd yang berada di bodi sistem tersebut. Hasil dari pengujian sistem ini menunjukkan bahwa sistem memberikan hasil nilai dari sensor, sensor $\mathrm{pH}$ memberikan hasil jika larutan asam dalam air semakin tinggi maka nilai sensor $\mathrm{pH}$ akan semakin menurun, setelah itu sensor kekeruhan memberikan hasil jika semakin keruh air nilai sensor kekeruhan akan semakin tinggi, dan terakhir Hasil nilai dari sensor suhu, semakin panas suhu air maka semakin meningkat pula nilai sensor suhu pada lcd.

Penelitian (5) yang dilakukan Hidayatullah dkk [6][7] menghasilkan Prototype sistem pemantauan kualitas air kolam dapat bekerja secara baik dengan mengukur parameter seperti suhu, kekeruhan dan pH. Penelitian (8) yang dilakukan Millah Hudiyah dkk [8] [9] menganalisis kualitas air bersih dari tangki air tanah. Penelitian (6) yang dilakukan Dewi Arianti Wulandari; Hendra Jatnika; Yudhy S. Purwanto [10] menganalisa datang dengan clustering data mining yaitu analisa pola hubungan barang terhadap pemesanan berdasarkan kebutuhan dan pemakaian. Selanjutnya akan dikenali pola-pola tersebut sehingga bisa didapatkan komposisi himpunan kriteria untuk pemesanan barang. Untuk menemukan pola-pola dan informasi dari sekumpulan koleksi data pemesanan menjadi bahan pengambilan keputusan .

Penelitian (7) yang diakukan Hasrianti dan Nurasia [11] dapat mengetahui kualitas kimia dan fisika air sumur bor di Kota Palopo. Kualitas kimia air yang diteliti meliputi analisis derajat keasamaan $(\mathrm{pH})$ dengan menggunakan $\mathrm{pH}$ meter, salinitas air dengan menggunakan salinometer. Penelitian (9) yang dilakukan bahrin dkk [12] [13] sistem kendali adalah suatu alat atau kumpulan alat untuk mengendalikan, memerintah, dan mengatur keadaan dari suatu sistem, singkatnya, sistem yang digunakan untuk membuat suatu perangkat menjadi terkendali sesuai dengan keinginan manusia.

Penelitian (10) yang dilakukan Ray Kasful Ghito dkk. [14] [15] Pembuatan smart garden system menggunakan Arduino Uno R3 dan Bluetooth HC-05 ini bertujuan untuk membantu pemilik gerai tanaman untuk melakukan pekerjaan dalam proses penyiraman secara otomatis.

Penelitian yang dilakukan oleh tim penulis dianggap dapat memenuhi kendala-kendala yang terjadi pada penelitian-penelitian di atas. Air bagi kehidupan manusia, maka kualitas air harus tetap terjaga dan dipertahankan kebersihannya. Suatu alat yang menggunakan Arduino Uno sebagai pengendali keseluruhan rangkaian, mendapatkan masukan dari sensor $\mathrm{pH}$ dan sensor Suhu yang akan dikenali oleh arduino. Lalu pada proses arduino akan mengeluarkan output yang berisi Bluetooth dan android. Alat ini akan mendeteksi kadar nilai $\mathrm{pH}$ air yang akan di konsumsi secara tepat. Tim penulis menekankan pada pentingnya sistem monitoring kualitas air dengan pada penampungan air yang terintegrasi pada aplikasi berbasis web.

\section{METODOLOGI PENELITIAN}

Metodologi penelitian adalah proses atau cara ilmiah untuk mendapatkan data yang akan digunakan untuk keperluan penelitian. Tujuan penelitian secara umum pada dasarnya adalah sama, yaitu bahwa penelitian merupakan refleksi dari keinginan manusia yang selalu berusaha untuk mengetahui sesuatu. Berikut metodologi penelitian yang dilakukan oleh tim peneliti untuk Smart System untuk ketersediaan air bersih Desa Ciaruteun Ilir. 


\section{KILAT}

Vol. 10, No. 1, April 2021, P-ISSN 2089-1245, E-ISSN 2655-4925

DOI: https://doi.org/10.33322/kilat.v10i1.1042

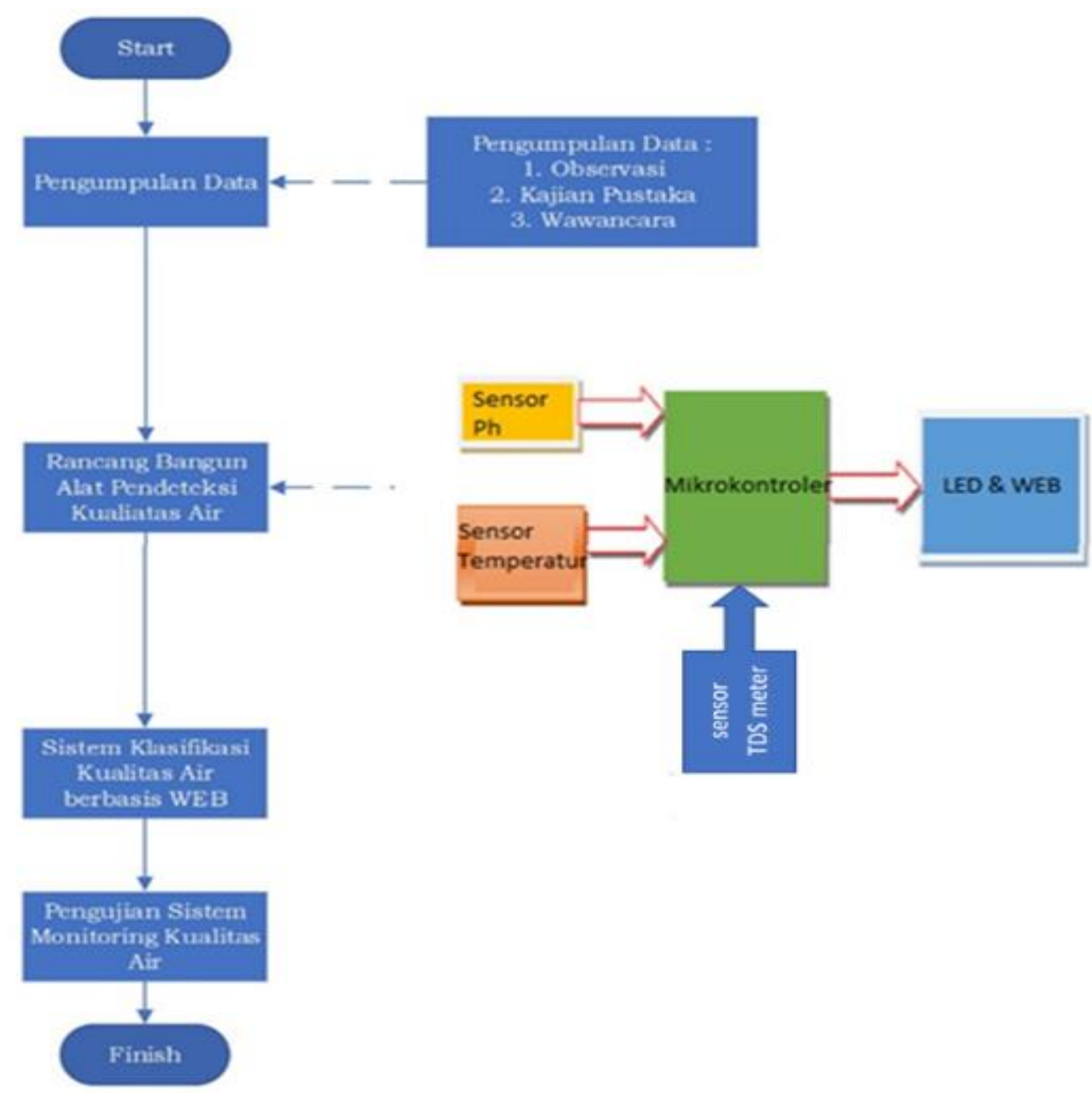

Gambar 5. Metodologi Penelitian

Penjelasan metode yang dilakukam peneliti diatas sebagai berikut:

1. Tahapan yang dilakukan pada pengumpulan data

a. Pengumpulan data tentang kondisi geografis wilayah desa ciaruteun ilir bogor melalui pengamatan langsung terkait kondisi air untuk dikonsumsi tujuannya untuk mengetahui kondisi air dan pengaruhnya dari letak geografis

b. Mengkaji melalui studi pustaka terkait desa ciaruteun ilir bogor dengan jurnal-jurnal terkait dan media masa/karya ilmiah tentang kondisi kualitas air desa ciaruteun ilir bogor tujuannya untuk mendapatkan referensi yang akurat

c. Menggali informasi lebih dalam melalui dan wawancara dengan kepala desa dan penduduk setempat tentang kondisi kualitas air dan solusi yang pernah dilakukan penduduk, tujuannya singronisasi dan validasi hasil wawancara dan kajian pustaka

d. Menetapkan indentifikasi dan rumusan masalah

e. Menetapkan alternanif solusi dari permasalahan 
2. Tahapan yang dilakukan pada rancang bangun alat pendeteksi kualitas air

a. Perancangan Sistem

Dalam merancang sistem ini, kita dapat merancang sistem dengan dua tahap perancangan yaitu perancangan perangkat keras dan perancangan perangkat lunak. Langkah pertama dalam perancangan sistem ini yaitu membuat blok diagram perangkat keras, kemudian dilanjutkan dengan membuat minimum sistem Arduino Uno dan rangkaian-rangkaian sensor. Langkah kedua yaitu membuat perangkat lunak/perintah yang digunakan untuk mengoperasikan Arduino Uno.

b. Perancangan Perangkat Keras

Perancangan perangkat keras terdiri dari sistem kontrol yaitu Arduino yang bertugas sebagai pengendali sensor serta melakukan pengolahan data. Perancangan sistem dipresentasikan dalam bentuk blok diagram yang akan membantu dalam membuat perancangan alat "Pemantauan Kualitas Air Sawah Berbasis Android" dengan menggunakan Arduino Uno sebagai pengolah data, sensor pH air dan sensor suhu LM35.

c. Perancangan Perangkat Lunak

Setelah perancangan perangkat keras selesai dikerjakan maka langkah selanjutnya adalah perancangan perangkat lunak (program perintah). Perancangan perangkat lunak menggunakan software Arduino yang selanjutnya di download-kan pada Arduino Uno. Setelah itu membuat aplikasi android menggunakan software MIT inventor yang kemudian dihubungkan ke software arduino UNO.

d. Pemrograman Arduino

Pembuatan software baris kode program dilakukan dengan menggunakan aplikasi ide arduino versi 1.8.1 dengan basis bahas c yang disesuaikan agar dapat menunjang kinerja alat secara keseluruhan.

e. Merakit Sensor Dallas DS18B20 yang digunakan untuk membaca suhu air karena sensor Dallas DS18B20 adalah sensor dengan kemampuan tahan air (waterproof), sensor ini terdiri dari 3 pin yaitu vcc, gnd dan data. Keluaran dari sensor DS18B20 sudah berbentuk digital dengan resolusi sensor 9-bit. Sensor ini memiliki kisaran suhu dari $-55 \mathrm{oC}-+125 \mathrm{oC}$. Dallas DS18B20 dapat dihubungkan dengan mikrokontroler lewat antarmuka 1 Wire. Sensor ini dikemas secara khusus sehingga kedap air.

f. Merakit Sebuah sensor $\mathrm{pH}$ Meter adalah instrumen ilmiah yang mengukur konsentrasi hidrogen-ion (atau $\mathrm{pH}$ ) dalam suatu larutan, menunjukkan keasaman atau alkalinitas. $\mathrm{pH}$ meter mengukur perbedaan potensial listrik antara elektroda $\mathrm{pH}$ dan elektroda referensi. Biasanya memiliki elektroda kaca ditambah elektroda referensi kalomel, atau elektroda kombinasi. Selain mengukur $\mathrm{pH}$ cairan, probe khusus kadang-kadang digunakan untuk mengukur $\mathrm{pH}$ zat semi-padat. Rangkaian pengukuranya tidak lebih dari sebuah voltmeter yang menampilkan pengukuran dalam $\mathrm{pH}$ selain volt. Pengukuraan impedansi input harus sangat tinggi karena adanya resistansi tinggi (sekitar 20 hingga $1000 \mathrm{ohm}$ ) pada probe elektroda yang biasa digunakan dengan $\mathrm{pH}$ meter. Dalam penggunaan analog $\mathrm{pH}$ meter kit tingkat keasaman/kebasaan dari suatu zat ditentukan berdasarkan keberadaan jumlah ion hidrogen dan ion hidroksida dalam larutan air.

g. Merakit Sirkuit $\mathrm{pH}$ adalah perangkat yang sangat sensitif. Sensitivitas ini adalah apa yang memberikan rangkaian $\mathrm{pH}$ dan akurasinya. Ini juga berarti bahwa rangkaian $\mathrm{pH}$ mampu membaca mikro-tegangan yang berdarah ke dalam air dari sumber alami seperti pompa, katup solenoid atau sensor lainnya. Ketika gangguan listrik bercampur dengan $\mathrm{pH}$ bacaan itu adalah umum untuk melihat cepat berfluktuasi bacaan atau bacaan yang konsisten off. 


\section{KILAT}

Vol. 10, No. 1, April 2021, P-ISSN 2089-1245, E-ISSN 2655-4925

DOI: https://doi.org/10.33322/kilat.v10i1.1042

Untuk memverifikasi bahwa gangguan listrik yang menyebabkan tidak akurat bacaan menempatkan probe $\mathrm{pH}$ dalam secangkir air.

h. Merakit sensor TDS meter yang merupakan sensor kompatibel Arduino yang digunakan untuk mengukur kadar TDS (Total Dissolve Solid ) pada air. TDS sendiri merupakan kadar konsentrasi objek solid yang terlarut dalam air, Sensor ini mendukung input tegangan antara $3.3-5 \mathrm{~V}$, serta output tegangan analog yang dihasilkan berkisar pada $0-2.3 \mathrm{~V}$

i. Pengujian Smart System untuk ketersediaan air bersih Desa Ciaruteun Ilir.

j.

\section{Hasil}

Hasil dari penelitian ini adalah sebuah alat yang bernama ALUKAR (Alat Ukur Kualitas Air) dan sebuah aplikasi web yang memberikan dan menyimpan data kualitas air. Kedua alat dan aplikasi tersebut saling terintegrasi satu sama lain.

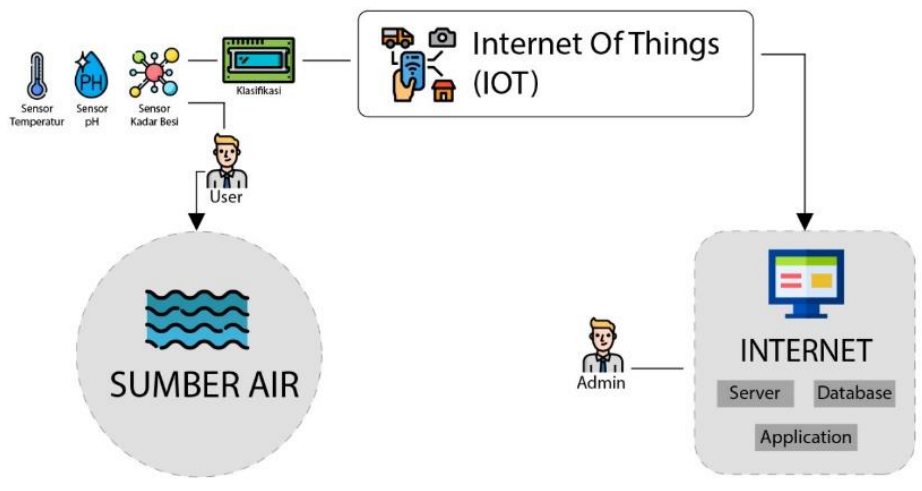

Gambar 6. Alur Pemakaian ALUKAR

\subsection{Alat}

Sementara cara pembuatan alat sekaligus dengan sofware dan bahasa pemrograman yang digunakan adalah sebagai berikut:

Tabel 1. Software yang digunakan

\begin{tabular}{|c|l|l|}
\hline No & Nama Software & Kegunaan \\
\hline 1 & Arduino IDE & $\begin{array}{l}\text { Sebagai tempat untuk pengembangan aplikasi, dan untuk } \\
\text { mengupload program ke dalam alat Arduino. }\end{array}$ \\
\hline 2 & XAMPP & Sebagai tempat pengembangan aplikasi web \\
\hline 3 & Sublime Text (Text Editor) & Untuk mengedit source code \\
\hline 4 & Browser & Untuk melihat aplikasi Alukar \\
\hline
\end{tabular}

Tabel 2. Bahasa pemrograman yang digunakan

\begin{tabular}{|c|l|l|}
\hline No & Bahasa Pemrograman & Area penggunaan \\
\hline 1 & C++ & Pengembangan aplikasi di Arduino \\
\hline 2 & PHP (versi 7.3.1) & Pengembangan aplikasi web \\
\hline
\end{tabular}

Tabel 3. Perangkat yang digunakan

\begin{tabular}{|c|l|l|}
\hline No & Nama Perangkat & Kegunaan \\
\hline 1 & Arduino UNO & $\begin{array}{l}\text { Sebagai pengendali sensor serta melakukan pengolahan } \\
\text { data. }\end{array}$ \\
\hline
\end{tabular}




\begin{tabular}{|c|l|l|}
\hline 2 & Sensor suhu DS18B20 & $\begin{array}{l}\text { Berfungsi untuk membaca suhu air karena sensor Dallas } \\
\text { DS18B20 berkemampuan tahan air (waterproof), sensor ini } \\
\text { terdiri dari 3 pin yaitu vcc, gnd dan data }\end{array}$ \\
\hline 3 & Sensor pH Meter & $\begin{array}{l}\text { Berfungsi untuk mengukur konsentrasi hidrogen-ion (atau } \\
\text { pH) dalam suatu larutan, menunjukkan keasaman atau } \\
\text { alkalinitas }\end{array}$ \\
\hline 4 & Modul GSM SIM 800 & $\begin{array}{l}\text { Berfungsi untuk melakukan pengiriman data dari arduino } \\
\text { ke web server }\end{array}$ \\
\hline $\mathbf{5}$ & Sensor TDS Meter & Berfungsi untuk mengukur total TDS (total dissolved solid) \\
\hline
\end{tabular}

\subsection{Cara pembuatan alat}

1. Alat dirangkai sesuai dengan ketentuan tiap komponen.

2. Merancang source code program untuk sensor temperatur, $\mathrm{pH}$, kadar logam, LCD, dan modul GSM. Setiap source code dites untuk memastikan tiap komponen sudah berjalan dengan baik.

3. Setiap source code program untuk tiap sensor, LCD, dan Modul GSM digabung menjadi satu (setiap kode sensor dibuat dalam satu function) menjadi 1 source code, yaitu source code Alukar.

4. Merancang alur aplikasi dan desain database. Setelah itu membuat aplikasi web, lalu diuji apakah Alukar bisa mengirim data ke web.

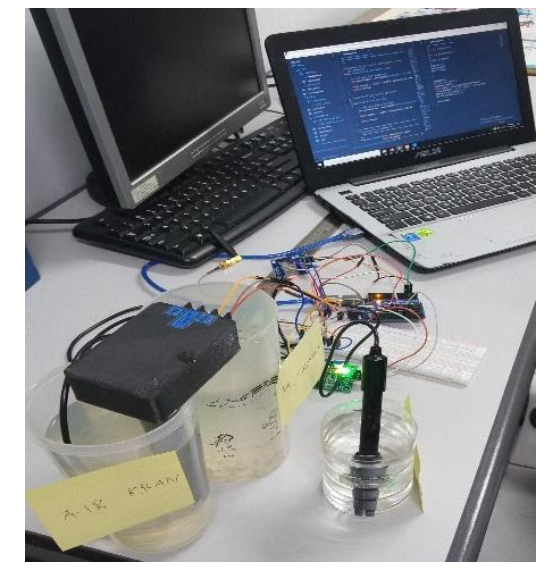

Gambar 7. Rangkaian Elektronik Alukar

\subsection{Hasil Uji Alukar}

Hasil uji alat menghasilkan data seperti yang tertera pada tabel di bawah ini:

Tabel 4. pengujian alat ALUKAR

\begin{tabular}{|c|l|l|l|c|}
\hline No & \multicolumn{1}{|c|}{ Pengujian } & \multicolumn{1}{|c|}{ Test Case } & \multicolumn{1}{c|}{ Hasil pengujian } & Kesimpulan \\
\hline 1 & Menyalakan alat & $\begin{array}{l}\text { User menhubungkan alat } \\
\text { ke Power Bank }\end{array}$ & Alat Menyala & Valid \\
\hline 2 & $\begin{array}{l}\text { Menampilkan data } \\
\text { pengukuran sensor }\end{array}$ & $\begin{array}{l}\text { User menempelkan } \\
\text { sensor ke dalam air yang } \\
\text { diuji }\end{array}$ & $\begin{array}{l}\text { Muncul data pengukuran } \\
\text { di LCD }\end{array}$ & Valid \\
\hline
\end{tabular}




\section{KILAT}

Vol. 10, No. 1, April 2021, P-ISSN 2089-1245, E-ISSN 2655-4925

DOI: https://doi.org/10.33322/kilat.v10i1.1042

Tabel 5. pengujian koneksi alat dengan Handphone

\begin{tabular}{|c|c|l|l|c|}
\hline No & Pengujian & \multicolumn{1}{|c|}{ Test Case } & \multicolumn{1}{c|}{ Hasil pengujian } & Kesimpulan \\
\hline 1 & & $\begin{array}{l}\text { User memasukkan kartu SIM, } \\
\text { lalu menyalakan ALUKAR, } \\
\text { dan memasukkan sensor ke air }\end{array}$ & $\begin{array}{l}\text { Alat menyala, lalu mulai } \\
\text { muncul data di HP }\end{array}$ & Valid \\
\cline { 3 - 5 } & $\begin{array}{l}\text { Mengirim data } \\
\text { ke web server }\end{array}$ & $\begin{array}{l}\text { User menyalakan ALUKAR, } \\
\text { dan tidak memasukkan sensor } \\
\text { ke air }\end{array}$ & $\begin{array}{l}\text { Alat menyala, lalu mulai } \\
\text { muncul data 0 }\end{array}$ & Valid \\
\hline
\end{tabular}

Tabel 6. pengujian koneksi alat dengan Web

\begin{tabular}{|c|c|c|c|c|}
\hline No & Pengujian & Test Case & Hasil pengujian & Kesimpulan \\
\hline \multirow{2}{*}{1} & \multirow{2}{*}{$\begin{array}{l}\text { Alat siap } \\
\text { mengirim data }\end{array}$} & $\begin{array}{l}\text { User memasukkan kartu SIM } \\
\text { yang konektivitasnya rendah, } \\
\text { lalu menyalakan ALUKAR }\end{array}$ & $\begin{array}{l}\text { Alat menyala, namun terus } \\
\text { mencari sinyal }\end{array}$ & Valid \\
\hline & & $\begin{array}{l}\text { User memasukkan kartu SIM } \\
\text { dengan konektivitas tinggi, lalu } \\
\text { menyalakan ALUKAR }\end{array}$ & $\begin{array}{l}\text { Alat menyala, dan terlihat } \\
\text { bahwa modul GSM sudah } \\
\text { terhubung ke Jaringan }\end{array}$ & Valid \\
\hline \multirow{3}{*}{2} & \multirow{3}{*}{$\begin{array}{l}\text { Mengirim data } \\
\text { ke dalam web } \\
\text { server }\end{array}$} & $\begin{array}{l}\text { User memasukkan kartu SIM, } \\
\text { lalu menyalakan ALUKAR, } \\
\text { dan memasuk kan sensor ke air }\end{array}$ & $\begin{array}{l}\text { Alat menyala, lalu mulai } \\
\text { muncul data di halaman } \\
\text { web setiap interval waktu }\end{array}$ & Valid \\
\hline & & $\begin{array}{l}\text { User memasukkan kartu SIM, } \\
\text { menyalakan ALUKAR, dan } \\
\text { tidak memasukkan sensor ke } \\
\text { air }\end{array}$ & $\begin{array}{l}\text { Alat menyala, lalu mulai } \\
\text { muncul data } 0\end{array}$ & Valid \\
\hline & & $\begin{array}{l}\text { User tidak memasukkan kartu } \\
\text { SIM, lalu menyala kan } \\
\text { ALUKAR, dan tidak } \\
\text { memasukkan sensor }\end{array}$ & $\begin{array}{l}\text { ALUKAR menyala, namun } \\
\text { tidak ada data yang masuk } \\
\text { di website }\end{array}$ & Valid \\
\hline
\end{tabular}

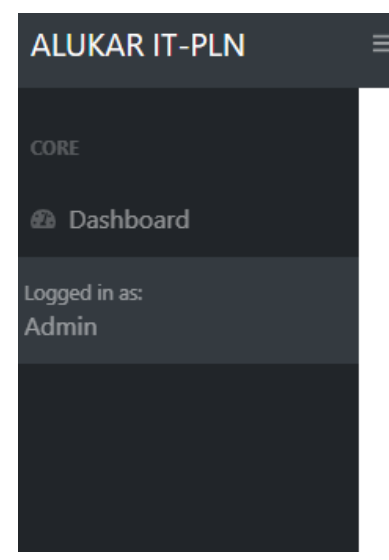

\section{Dashboard}

Dashboard Monitoring Alat Ukur Kualitas Air
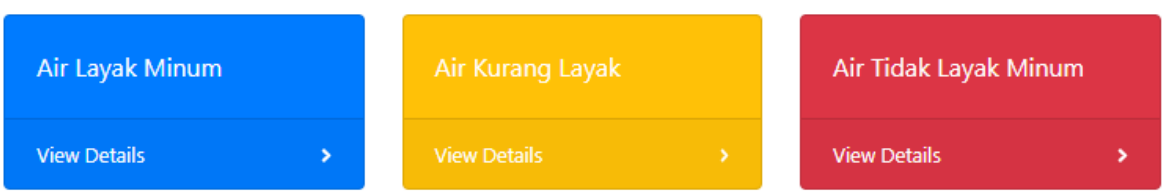

Gambar 8. Tampilan Dashboard ALUKAR 


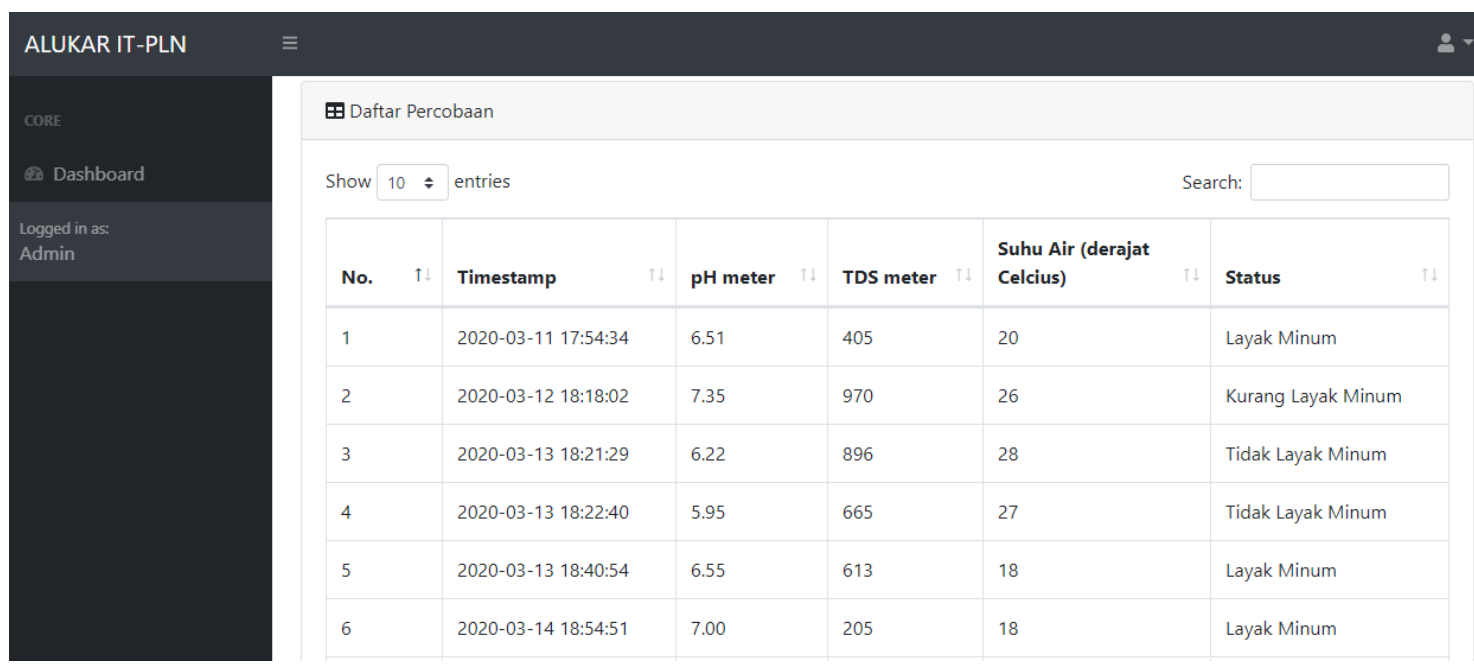

Gambar 9. Tampilan Data ALUKAR

\subsection{Kesimpulan}

Dari proses pembuatan dan pengujian Alat Ukur Kualitas Air (ALUKAR) di atas, dapat disimpulkan bahwa:

1. Alukar dapat menjadi satu solusi bagi masyarakat untuk dapat mengetahui kualitas air yang akan digunakannya.

2. Alukar dengan sistem web databasenya dapat memprediksi kualitas air pada musim-musim atau waktu-waktu tertentu di suatu daerah.

3. Alukar dibuat portable sehingga dapat menjangkau sumber-sumber air yang terpencil dengan tingkat keakuratan yang tinggi.

4. Pengembangan Alukar dapat dilakukan dengan menambahkan beberapa fitur pemeriksaan kualitas air lainnya, seperti: kadar mineral, kandungan bahan kimia, dll. dan juga pada web dapat ditambahkan kecocokan kualitas air dengan penggunaannya.

\section{DAFTAR PUSTAKA}

[1] Umar, "Warga Desa Ciaruteun Ilir Butuh Air bersih," 2019, 2019. http://topbogor.com/wargadesa-ciaruteun-ilir-butuh-air-bersih/.

[2] M. Abdullah, E. Susanto, and I. P. D. Wibawa, "Rancang Bangun Sistem Pendeteksi Kualitas Air Menggunakan Metode Fuzzy Logic Universitas Telkom," e-Proceeding Eng., vol. 3, no. 2, pp. 1321-1326, 2016, [Online]. Available: https://openlibrary.telkomuniversity.ac.id/home/epublication/id/90.html.

[3] F. Ariska and I. Hadi, "Perancangan Alat Pendeteksi Kualitas Air Berbasis Android," pp. 173176, 2019.

[4] R. Istoni, "Implementasi Sistem Monitoring Kualitas Air Berbasis Intellegent Sensor Ph Dan Temperatur Pada Wtp Pnj," Fakt. Exacta, vol. 11, no. 2, p. 158, 2018, doi: 10.30998/faktorexacta.v11i2.2342.

[5] A. F. Machzar, S. R. Akbar, and H. Fitriah, "Implementasi Sistem Monitoring Kualitas Air Pada Budidaya Tambak Udang dan Bandeng," J. Pengemb. Teknol. Inf. dan Ilmu Komput., vol. 2, no. 10, pp. 3458-3465, 2018.

[6] M. Hidayatullah, J. Fat, and T. Andriani, "Prototype Sistem Telemetri Pemantauan Kualitas Air Pada Kolam Ikan Air Tawar Berbasis Mikrokontroler," Positron, vol. 8, no. 2, p. 43, 2018, doi: 10.26418/positron.v8i2.27367. 


\section{KILAT}

Vol. 10, No. 1, April 2021, P-ISSN 2089-1245, E-ISSN 2655-4925

DOI: https://doi.org/10.33322/kilat.v10i1.1042

[7] E. Ihsanto and S. Hidayat, "RANCANG BANGUN SISTEM PENGUKURAN Ph METER DENGAN MENGGUNAKAN MIKROKONTROLLER ARDUINO UNO,”J. Teknol. Elektro, vol. 5, no. 3, 2014, doi: 10.22441/jte.v5i3.769.

[8] Millah Hudiyah, "Analisis Kualitas Air pada Jalur Distribusi Air Bersih di Gedung Baru Fakultas Ekonomi dan Manajemen Institut Pertanian Bogor," J. Tek. Sipil dan Lingkung., vol. 3, no. 2, pp. 93-104, 2019, doi: 10.29244/jsil.3.2.93-104.

[9] E. B. Sasongko, E. Widyastuti, and R. E. Priyono, "Kajian Kualitas Air Dan Penggunaan Sumur Gali Oleh Masyarakat Di Sekitar Sungai Kaliyasa Kabupaten Cilacap," J. Ilmu Lingkung., vol. 12, no. 2, p. 72, 2014, doi: 10.14710/jil.12.2.72-82.

[10] Dewi Arianti Wulandari; Hendra Jatnika; Yudhy S. Purwanto, "Rancang Bangun Aplikasi Clustering Data Mining Menggunakan Metode K-Means Dan K-Modes," Kilat, vol. 7, no. 1, pp. 30-35, 2018, doi: 10.33322/kilat.v7i1.96.

[11] Hasrianti and Nurasia, "ANALISIS WARNA, SUHU, pH DAN SALINITAS AIR SUMUR BOR DI KOTA PALOPO,” Anal. Warn. SUHU, pH DAN Salin. AIR SUMUR BOR DI KOTA PALOPO, vol. 02, pp. 747-753, 2016.

[12] B. Bin Dahlan, "Sistem Kontrol Penerangan Menggunakan Arduino Uno Pada Universitas Ichsan Gorontalo," Ilk. J. Ilm., vol. 9, no. 3, pp. 282-289, 2017, doi: 10.33096/ilkom.v9i3.158.282-289.

[13] R. Rizal, I. Karyana, and Ruuhwan, "Sistem Kendali dan Monitoring pada Smart Home Berbasis Internet of Things (IoT)," no. October, 2019.

[14] R. K. Ghito and N. Nurdiana, "Rancang Bangun Smart Garden System Menggunakan Sensor Soil Moisture dan Arduino Berbasis Android (Studi Kasus : : Di Gerai Bibit Narnea Cikijing)," Univ. Majalengka, pp. 166-170, 2018.

[15] D. Kurnia and A. A. Suprianto, "Rancang Bangun Prototipe Gardening Smart System (Gss) Untuk Perawatan Tanaman Anggrek Berbasis Web," Simetris J. Tek. Mesin, Elektro dan Ilmu Komput., vol. 7, no. 1, p. 191, 2016, doi: 10.24176/simet.v7i1.504. 